\title{
PROFIL KESALAHAN PENGETAHUAN DEKLARATIF GURU SD DALAM MEMBELAJARKAN BANGUN DATAR
}

\author{
Zainuddin Untu \\ Dosen Pendidikan Matematika FKIP Universitas Mulawarman \\ Email: zainuddin.untu70@gmail.com
}

\begin{abstract}
ABSTRAK
Penelitian ini bertujuan untuk mengetahui profil kesalahan guru mendeklarasikan materi bangun datar dalam pembelajaran matematika di kelas VI SD. Subjek penelitian ini adalah guru kelas VI Sekolah Dasar Negeri 02 Samarinda Ilir kota Samarinda Kalimantan Timur. Pengambilan data dilakukan melalui observasi selama proses pembelajaran matematika materi bangun datar dan wawancara setelah pembelajaran. Hasil penelitian menunjukan bahwa profil kesalahan guru dalam membelajarkan luas bangun datar adalah kesalahan didalam mendeklarasikan konsep dan fakta mengenai luas dan keliling bangun datar baik secara tertulis atau gambar maupun secara lisan.
\end{abstract}

Kata kunci: Profil Kesalahan, Pengetahuan Deklaratif, Pembelajaran Matematika

\begin{abstract}
This study aims to determine the teacher's error profile declaring material flat build in mathematics learning in grade VI elementary school. The subjects of this study were grade VI 02 Samarinda Ilir Primary School teacher, Samarinda city of east Kalimantan. Data retrieval is done through observation during the mathematics learning process flat wake material and interviews after learning. The result showed that the teacher's error profile in learning the area of flat shape was an error in declaring concept and fact about the area and circumference of flat shape both in writing or in pictures or verbally.
\end{abstract}

Keywords: Error Profile, Declarative Knowledge, Mathematic Learning

\section{PENDAHULUAN}

Pengetahuan deklaratif (declarative knowledge) adalah pengetahuan tentang sesuatu hal sebenarnya yang biasa dideklarasikan dalam bentuk kata-kata atau disebut juga sebagai pengetahuan konseptual (Hoy \& Miskel, 2005). Sedangkan Clark dan Mayer (2007) menjelaskan bahwa pengetahuan deklaratif merupakan pengetahuan tentang sesuatu (about something) yang dapat dideklarasikan dengan kata-kata baik secara lisan maupun secara tertulis. Berdasarkan dua pendapat ini, dapat diartikan bahwa pengetahuan deklaratif adalah pengetahuan tentang konsep dan fakta yang dideklarasikan/dideskrip- 
sikan dengan kata-kata (kalimat) secara lisan dan/atau secara tertulis.

Dalam kaitannya dengan pengertian pengetahuan deklaratif di atas, Anderson, dkk (2001) menguraikan pengetahuan deklaratif atas dua jenis pengetahuan yaitu pengetahuan faktual (factual knowledge) dan pengetahuan konseptual (conceptual knowledge). Pengetahuan faktual merupakan pengetahuan tentang elemen-elemen dasar dari suatu topik materi. Sedangkan pengetahuan konseptual merupakan pengetahuan tentang hubungan pertalian antara elemenelemen dasar dari suatu topik materi dan kaitannya dengan klasifikasi, kategori, prinsip-prinsip, generalisasi, teori, model, dan struktur.

Pengetahuan deklaratif diperlukan oleh pendidik matematika sebagai dasar dan substansi untuk membelajarkan konsep dan fakta matematika secara bermakna. Sedangkan bagi peserta didik, pengetahuan deklaratif diperlukan sebagai dasar untuk memahami fakta dan konsep-konsep matematika yang sedang dipelajari serta untuk memahami dan mempelajari fakta dan konsep-konsep matematika pada pelajaran berikutnya. Uraian ini sesuai dengan salah satu penjelasan dalam Australian Curriculum Assessment and Reporting Authority (ACARA, 2012) bahwa, penguasaan pengetahuan deklaratif bagi guru matematika merupakan kunci keberhasilan di dalam membelajarkan konsep-konsep matematika. Meskipun pengetahuan deklaratif merupakan hal penting dalam pembelajaran matematika namun yang menjadi permasalahan adalah pengetahuan deklaratif sering dikesam-pingkan oleh para guru karena dianggap sebagai pengetahuan yang semata-mata hanya menghafal, tidak menarik, dan tidak penting (ACARA, 2012).

Permasalahan yang terjadi dalam dunia pendidikan dan pembelajaran matematika saat ini sering dikaitkan dengan pengetahuan konseptual dan pengetahuan faktual guru. Ini artinya pengetahuan deklaratif guru dalam membelajarkan matematika masih rendah. Salah satu hasil studi tentang rendahnya tingkat pengetahuan deklaratif guru dalam pembelajaran matematika di Indonesia adalah studi yang dilakukan oleh Subanji (2007) yang menjelaskan bahwa kebanyakan pengajar matematika hanya mengajarkan matematika secara prosedur tanpa menjelaskan mengapa prosedur tersebut digunakan dan mengapa prosedur tersebut yang digunakan. Ini sesuai dengan hasil pengamatan penulis terhadap guru SD saat membelajarkan keliling dan luas bangun datar di kelas VI.

Berdasarkan hasil pengamatan diketahui bahwa, di dalam mendeskripsikan contoh permasalahan luas dan keliling bangun datar, guru hanya menuliskan deskripsi penyelesaian contoh soal tersebut di papan tulis seperti yang tertera dalam buku paket pegangan siswa dan dibacakan tanpa diberi penjelasan. Fenomena ini sebagai salah satu indikasi rendahnya tingkat pengetahuan deklaratif guru tersebut dalam membelajarkan matematika materi bangun datar.

Rendahnya pengetahuan deklaratif seo-rang guru dalam membelajarkan matematika dapat menyebabkan guru salah mendekla-rasikan penyampaian konsep matematika yang dibelajarkan. Ashlock (2006) men-jelaskan bahwa, dua hal yang berkaitan dengan pemahaman konseptual 
pada penge-tahuan deklaratif yang sering menyebabkan kesalahan (miskonsepsi) dalam pembelajaran matematika yaitu overgeneralize dan overspecialize. Salah satu contoh over-generalize misalnya memberi nama gambar suatu segitiga atau segiempat berdasarkan posisinya. Sedangkan contoh overspecialize antara lain misalnya percaya bahwa, ukuran tinggi suatu segitiga hanya dapat ditemukan di dalam segitiga, selalu harus menyamakan penyebut ketika menyelesaikan soal-soal operasi penjumlahan dan pengurangan bilangan pecahan, dalam pembelajaran matematika. Contoh misalnya, $\frac{2}{3}+\frac{1}{4}=$ $\frac{8}{12}+\frac{3}{12}=\frac{11}{12}$ dan $\frac{3}{4}-\frac{2}{5}=\frac{15}{20}-\frac{8}{20}=$ $\frac{7}{20}$. Dan bahkan ketika mengalikan dua bilangan pecahan. Contohnya, $\frac{1}{2} \times \frac{2}{3}=\frac{3}{6}$ $\times \frac{4}{6}=\frac{12}{36}$. Marzano (2009) mengemukakan bahwa empat kategori kesalahan umum dalam pengetahuan deklaratif yaitu salah dalam menyajikan informasi yang saling berten-tangan, salah karena tidak dapat memaknai argumen terhadap pengecualian berdasarkan aturan, salah akibat membingungkan temporal (waktu) urutan peristiwa dengan kausalitas atau terlalu menyederhanakan alasan dibalik beberapa kejadian atau peristiwa, dan salah mengajukan pertanyaan dan kemudian membuat klaim berdebat dengan hanya menggunakan pernyataan yang setara dengan pernyataan klaim.

Penelitian tentang pengetahuan deklaratif telah dilakukan oleh Madalina Tanase (2011) tentang pengajaran konsep nilai tempat. Miller dan Hudson (2007) tentang pengetahuan konseptual merupakan pedoman pembelajaran di dalam memprak- tekkan kurikulum matematika yang komprehensif pada semua materi matematika. Slava Kalyuga (2009) tentang sebuah perspektif beban kognitif; belajar dan mengajar. Stürmer, Könings dan Seidel (2012) tentang tiga aspek kemampuan dan visi profesional guru dalam pengetahuan deklaratif (menggambarkan, menjelaskan, dan memprediksi situasi kelas).

Dari beberapa hasil penelitian di atas, belum ada yang mengungkap tentang profil kesalahan pengetahuan deklaratif guru dalam membelajarkan matematika materi bangun datar. Atas dasar inilah dilakukan penyelidikan tentang profil kesalahan pengetahuan deklaratif guru dalam membelajarkan materi bangun datar di kelas VI SD. Kesalahan yang dibahas dalam tulisan ini difokuskan pada kesalahan guru dalam mendeskripsikan secara tertulis dan secara lisan penyajian materi (konsep dan fakta) dalam pembelajaran matematika materi bangun datar di Kelas VI SD. Dipilihnya materi bangun datar karena materi ini merupakan dasar bagi siswa SD untuk mempelajari dan memahami materi bangun ruang.

\section{METODE PENELITIAN}

Metode yang digunakan dalam penelitian ini adalah deskriptif dengan pendekatan kualitatif. Penelitian dilakukan di SD Negeri 02 Samarinda Ilir Kota Samarinda Provinsi Kalimantan Timur pada bulan Januari Tahun 2018. Subjek penelitian adalah Guru Kelas VI dan obyek penelitian adalah profil kesalahan pengetahuan deklaratif guru dalam mendeklarasikan penyampaian materi bangun datar dalam pembelajaran matematika. Pengumpulan data dilakukan melalui 
observasi dan wawancara dengan mempergunakan format pengamatan dan pedoman wawancara yang sudah divalidasi.

Observasi dilakukan dengan cara mengamati dan merekam kegiatan subjek saat membelajarkan materi Bangun Datar. Obser-vasi bertujuan untuk melihat secara langsung profil kesalahan pengetahuan deklaratif guru di dalam membelajarkan materi bangun datar. Sedangkan wawancara dengan subjek di-lakukan setelah pelaksanaan pembelajaran. Wawancara ini berbasis video dengan tujuan untuk menggali dan mengklarifikasi hal-hal terkait dengan pengetahuan deklaratif dan kesalahan guru yang terjadi di dalam membelajarkan materi bangun datar di Kelas VI SD. Data yang diperoleh dalam penelitian ini dianalisis secara kualitatif.

\section{HASIL PENELITIAN DAN PEMBA- HASAN}

Pengetahuan deklaratif yang dimiliki oleh seorang guru matematika, akan sangat membantu guru tersebut di dalam memecahkan permasalahan dalam pembelajaran matematika. Solaz-Portoles (2008) menjelaskan bahwa, secara garis besar salah satu komponen utama pengetahuan yang dibutuhkan untuk memecahkan dan menyelesaikan masalah dalam pembelajaran adalah faktual dalam pengetahuan deklaratif.

Friege dan Lind (2006) mengemukakan bahwa, pengetahuan deklaratif merupakan prediktor yang sangat baik untuk mengatasi masalah kinerja, termasuk kinerja guru dalam mendeskripsikan materi di dalam membelajarkan matematika. Ini berarti pengetahuan deklaratif bagi seorang guru matematika akan menjadi prediktor untuk mengatasi masalah dalam pembelajaran matematika. Cara yang ampuh bagi guru untuk memperdalam pemahamannya tentang pengetahuan deklaratif adalah menganalisis masalah dan kesalahannya dalam pem-belajaran (Marzano, 2009). Penjelasan ini dapat diartikan bahwa untuk memperdalam penguasaan guru matematika tentang pengetahuan deklaratif, perlu dilakukan penyelidikan mengenai kesalahan guru tersebut dalam membelajarkan matematika.

Berikut ini, dipaparkan profil kesalahan pengetahuan deklaratif guru dalam membelajarkan matematika materi bangun datar di kelas VI SD Negeri 02 Samarinda Ilir Kota Samarinda. Berdasarkan hasil pengamatan selama pembelajaran dan wawancara terhadap subjek (guru) setelah pembelajaran diketahui bahwa, didalam menuliskan penyelesaian masalah terkait dengan konsep luas dan keliling bangun datar yang diajarkan, guru tidak memperhatikan hal-hal yang bersifat faktual dan konseptual. Bahkan dalam menuliskan penyelesaian suatu permasa-lahan terkait dengan konsep luas dan keliling bangun datar yang dikemukakan sendiri, guru salah memahami dan salah menyampaikan konsep (miskonsepsi). Da-lam hal ini guru salah mendeskripsikan penyampaian konsep dan fakta keliling dan luas suatu bangun datar secara tertulis.

Dalam mendeskripsikan penyampaian konsep secara lisan, guru memberi penjelasan dengan mendeklarasikan bahwa "Anak-anak untuk menentukan luas bangun datar yang tampak pada gambar 1 ini kita harus membaginya menjadi tiga daerah yang terdiri dari satu persegi dan dua segitiga siku-siku yang kongruen". Dari penjelasan guru tersebut terlihat bahwa 
terjadi kesalahan di dalam mendeskripsikan konsep "persegi” baik lisan maupun tertulis. Dalam mendeskripsikan penyampaian konsep luas dan keliling bangun datar pada gambar 1 tersebut, guru mendeklarasikan bahwa, "Anak-anak untuk menentukan luas dan keliling bangun ini, kita harus membagi daerah bangun datar pada Gambar 1 ini menjadi 3 daerah terdiri dari 1 daerah persegi dan 2 daerah segitiga sikusiku yang kongruen dengan ukuran : sisi miring masing-masing $8 \mathrm{~cm}$, tinggi $6 \mathrm{~cm}$, dan alas masing-masing segitiga $4 \mathrm{~cm}$ " seperti terlihat pada gambar 1 . secara tertulis terkait gambar 1, diketahui bahwa guru melakukan kesahan. Dalam hal ini, guru "salah mendeskripsikan/mendeklarasikan konsep dan prinsip pythagoras secara tertulis maupun secara lisan". Fakta yang diperlihatkan melalui gambar 1 adalah salah satu hasil deskripsi penyajian materi (konsep) luas dan keliling bangun datar yang salah. Dalam hal ini salah mendeskripsikan/mendeklarasikan penyampaian konsep luas dan keliling suatu bangun datar dengan kata-kata, kalimat-kalimat, dan angka-angka baik secara tertulis/gam-

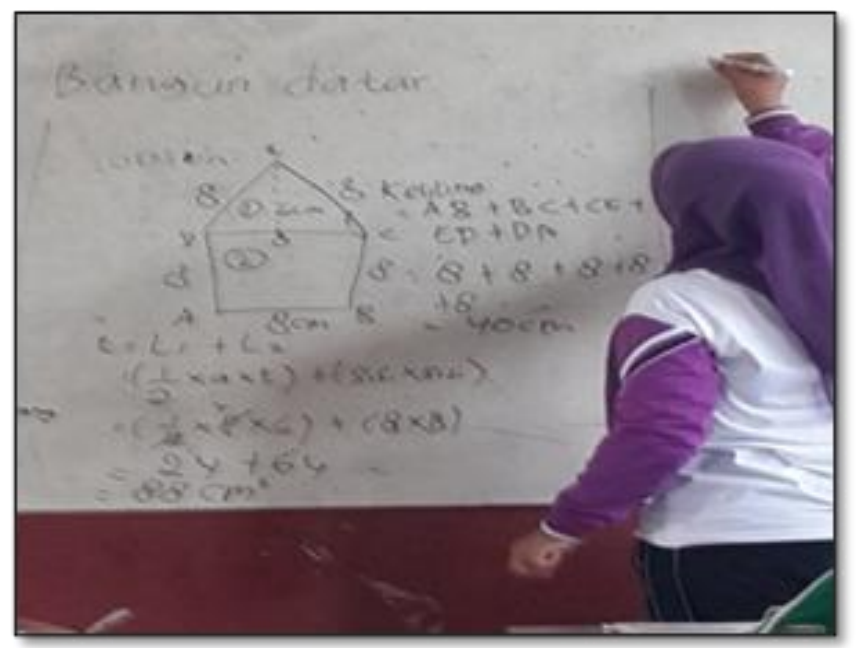

Gambar 1. Kegiatan guru mengkomunikasikan bangun datar

Berdasarkan hasil deskripsi (gambar bar maupun secara lisan/verbal dalam dan angka-angka) baik secara lisan maupun pembelajaran matematika.

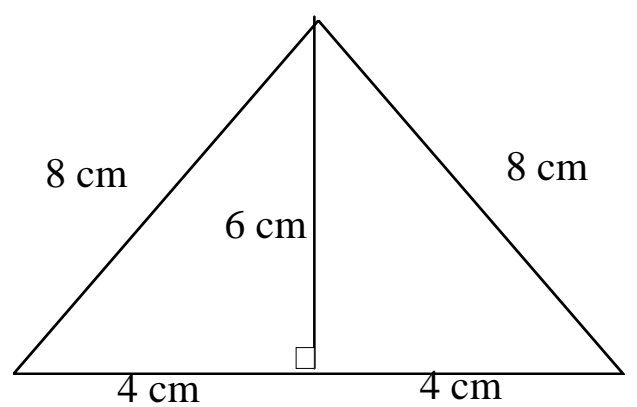

Gambar 2. Segitiga siku-siku yang dimaksud guru 
Kesalahan guru dalam mendeskripsikan mendeklarasikan penyajian konsep dan fakta luas dan keliling suatu bangun datar pada Gambar 1 di atas, terdiri dari : 1) salah dalam mendeskripsikan "konsep luas segitiga siku-siku" secara lisan yang ditunjukkan oleh pendeklarasian guru bahwa, " ... untuk menentukan luas dan keliling ..., kita harus membagi daerah bangun datar pada gambar 1 ini menjadi 3 daerah terdiri dari ... dan 2 daerah segitiga siku-siku yang kongruen dengan ukuran: sisi miring masing-masing $8 \mathrm{~cm}$, tinggi 6 $\mathrm{cm}$, dan alas masing-masing segitiga $4 \mathrm{~cm}$ " dan 2) salah dalam mendeklarasikan penyampaian konsep dan prinsip Pythagoras terkait dengan segitiga siku-siku yang dimaksud pada gambar 1 , karena $8^{2} \neq$ $6^{2}+4^{2}($ gambar 2$)$.

Fenomena ini merupakan suatu profil kesalahan pengetahuan deklaratif guru di dalam membelajarkan materi luas dan keliling bangun datar di kelas VI SD. Selama pembelajaran guru tidak menyadari adanya kesalahan yang dilakukan atau miskonsepsi yang terjadi di dalam mendeklarasikan penyampaian materi luas dan keliling bangun datar yang dibelajarkan. Kesalahan-kesalahan guru dalam membelajarkan materi luas dan keliling bangun datar di atas, diperkuat oleh petikan rekaman suara guru pada saat mendeklarasikan penyelesaian masalah luas dan keliling bangun datar dalam pembelajaran dan petikan hasil wawancara antara peneliti dengan guru setelah pembelajaran.

Berikut petikan rekaman suara guru saat pembelajaran.

Guru: Anak-anak untuk menyelesaikan masalah luas dan keliling tersebut, kita harus membagi daerah pada gambar ini menjadi 3 daerah yaitu 1 daerah persegi dan 2 daerah segitiga siku-siku yang kongruen dengan ukuran sisi miringnya masing-masing adalah $8 \mathrm{~cm}$, tingginya $6 \mathrm{~cm}$, dan ukuran alas masing-masing segitiga adalah 4 $\mathrm{cm}$.

Petikan hasil wawancara antara peneliti (P) dengan guru (S) setelah pembelajaran:

P5: Apa yang Ibu pikirkan ketika menggambar segi-lima seperti yang terlihat pada tayangan video ini

S5: Oo ... iya Pak, jadi tadi sebelum saya menggambar segi-lima di papan tulis, Saya menyampaikan bahwa, "anakanak kita akan menentukan luas dan keliling bangun segi-lima, perhatikan ya Ibu akan menggam-barkan bangun datar segi-lima". Jadi anakanak ... paham bahwa bangun datar ... di papan tulis itu adalah segi-lima. ... saya juga menyampaikan bahwa, “anak-anak untuk menentukan luas dan keliling dari bangun-bangun datar segi-lima ini kita harus membaginya atas tiga daerah (seperti terlihat pada tayangan video) yang terdiri dari satu daerah persegi dan dua daerah segi-tiga siku-siku yang kongruen".

P6: Menurut Ibu, apakah materi "luas dan keliling bangun datar" yang diajarkan tadi sudah benar?

S6: Iya Pak, saya yakin anak-anak itu hampir semuanya paham dengan baik. Tadi pada saat latihan mengerjakan contoh soal, banyak yang bersedia mengerjakan di papan tulis, dan sebagian besar bisa 
mengerjakan dengan benar di buku catatannya masing-masing.

P7: Mengapa Ibu merasa yakin seperti itu?

S7: Iya Pak karena selama saya mengajarkan materi luas dan keliling bangun datar ini, apalagi di Kelas VI jarang sekali saya sajikan materi dengan bantuan media alat peraga. ... kalau menyampaikan konsep "luas dan keliling" seperti ini cukup saya gambarkan model bangun datar itu di papan tulis dan dilengkapi dengan ukuran sisi-sisinya kemudian saya tanyakan caranya dan rumusnya kepada anak-anak seperti yang terdengar dan terlihat pada tayangan rekaman video ini Pak.

P9: ...., Apa yang Ibu pikirkan sehingga menyampaikan materi "luas dan keliling bangun datar" seperti terlihat pada tayangan rekaman video ini?

S9: Yaa... ada Pak. Pertama, saya pikir materi ini tidak terlalu sulit lagi untuk diajarkan kepada anak-anak di Kelas VI SD ini. Kedua, saya merasa sudah memahami materi ini dan saya sudah biasa mengajarkannya kepada anakanak di Kelas VI. Ketiga, materi "luas dan keliling bangun datar" ini sudah pernah dipelajari oleh anak-anak itu di kelas IV dan kelas V. Dan yang keempat, dengan cara penyampaian materi yang saya lakukan seperti yang terlihat pada tayangan rekaman video ini, saya yakin anak-anak akan bisa memahami dengan baik.

P10: Bagaimana perasaan Ibu setelah mengajarkan materi "Luas dan Keliling Bangun datar" tadi?

S10: Yaa... saya merasa senang sekali Pak karena walaupun ada Bapak, dan
Bapak merekam kegiatan pembelajaran tadi itu anak-anak tetap memperhatikan penyampaian dan penjelasan saya. Saya juga heran dan salut ....... mereka tidak terganggu dengan keberadaan Bapak di kelas. Jadi walaupun Bapak merekam kegiatan pembelajaran di kelas, anakanak tetap fokus pada pelajaran seperti biasa ...

Berdasarkan petikan hasil wawancara di atas, dapat dikatakan bahwa dalam membelajarkan materi "luas dan keliling bangun datar" ini, guru tidak menyadari adanya kesalahan yang dilakukan. Di samping itu guru tidak memprediksi situasi kelas. Dalam hal ini guru tidak menduga tentang adanya hal-hal yang mungkin dipikirkan dan yang akan dilakukan siswa setelah memperhatikan gurunya menulis, menggambar, dan mendeskripsikan atau mendeklarasikan konsep dan fakta luas dan keliling bangun datar yang diajarkan secara lisan. Sehingga akibatnya siswa mendeskripsikan (menggambar) bangun datar yang diajarkan gurunya tanpa memperhatikan konsep-konsep dasar yang harus dipelajari dan dipahami serta tanpa memperhatikan fakta-fakta yang akan diperlihatkan. Salah satu contoh hasil deskripsi (menggambar/menulis) siswa tentang konsep luas dan keliling dan hasil menggambar fakta bangun datar adalah seperti yang ditunjukkan pada gambar berikut.

Kenyataan bahwa guru tidak menyadari adanya kesalahan dan guru tidak memprediksi situasi kelas didukung oleh petikan hasil wawancara antara peneliti (P) dengan Guru (S) sebagai berikut: 
S3: Yaa ... saya mempelajari materinya dan berusaha untuk menyajikannya dengan baik kepada murid-murid di Kelas Pak.

P4: Oo... begitu. Selain mempelajari materinya, media apa saja yang dipersiapkan untuk mengajarkan "Luas dan Keliling Bangun Datar” ini?

S4: Ya ... biasanya saya membuat media alat peraga model-model bangun datar dari kertas karton, atau media-media matematika yang sudah ada di Sekolah. Tetapi hari ini saya tidak menyiapkan media-media itu makanya tadi saya mengajar tidak menggunakan media apapun.

P8: Mengapa Ibu tidak menyiapkan media ajar untuk mengajarkan materi "Luas dan Keliling Bangun Datar” tadi?

S8: Yaa... sebenarnya sengaja Pak Saya tidak menyiapkan media alat peraga itu karena saya merasa sudah bisa menyampaikan kepada murid-murid dengan baik, walaupun tadak menggunakan media alat peraga.

P13: Oke Bu. Apakah ada kendala di dalam membelajarkan materi "Luas dan Keliling Bangun Datar" tadi?

P16: Oo ... begitu ya Bu. Apakah dalam mengajar tadi Ibu pernah mesara sulit atau salah menulis atau menggambar atau keliru menyampaikan materi "konsep dan fakta" yang diajarkan?

S16: Belum pernah Pak. ...jadi selama saya menjelaskan materi "Luas dan Keliling Bangun Datar" tadi sampai saat ini, saya belum tau apakah ada kesalahan atau kekeliruan saya karena tadi itu sebelum dicatat oleh anak-anak, kita cek dan koreksi lagi bersama-sama. Dan kalau ada yang keliru atau salah biasanya anak-anak yang pintar langsung menanyakannya.

P17: Apakah selama membelajarkan materi keliling dan luas bangun datar tadi Ibu memprediksi situasi kelas?

S17: Kalau prediksi tidak Pak. Karena saya perhatikan anak-anak sudah memperhatikan dengan baik dan mungkin tidak ada masalah lagi.

Berdasarkan petikan hasil wawancara di atas, dapat diartikan bahwa kesalahan yang dilakukan guru di dalam membelajarkan materi luas dan keliling bangun datar bukan suatu kekeliruan atau kesalahan temporer, akan tetapi merupakan tindakan yang dilakukan dengan penuh percaya diri dan rasa tanggungjawab. Penulis menduga bahwa, kesalahan-kesalahan yang dilakukan dan yang akan dilakukan siswa terkait (konsep dan fakta) luas dan keliling bangun datar ini adalah akibat dari salah deskripsi penyajian materi oleh guru dalam pembelajaran.

Kesalahan-kesalahan ini sebagai indikasi bahwa, pengetahuan deklaratif guru tersebut rendah dan akan menye-babkan kesalahan-kesalahan pada siswa. Penulis juga menduga bahwa guru yang tidak menyadari kesalahannya ini sebagai akibat karena selama pembelajaran tidak memprediksi situasi kelas. Dalam membelajarkan materi luas dan keliling bangun datar, guru tidak memikirkan dan tidak memperhatikan apa yang dipikirkan dan akan dilakukan siswa terkait pendeskripsiannya dalam menyampaikan materi luas dan keliling bangun datar tersebut baik secara tertulis maupun secara lisan. 
Dalam upaya untuk menghasilkan pembelajaran yang efektif, seorang guru harus memiliki, memahami, dan dapat menerapkan pengetahuan deklaratifnya dalam pembelajaran. Hal ini sejalan dengan gagasan yang dikemukakan oleh Stürmer, Könings \& Seidel (2012) bahwa, tiga visi profesional dan kemampuan penting yang tergantung pengetahuan deklaratif yang dimiliki guru untuk mengimplementasikan pengetahuan pedagogis umum secara efektif dan signifikan yaitu kemampuan: (a) menggambarkan, (b) menjelaskan, dan (c) kemampuan memprediksi situasi kelas.

\section{KESIMPULAN}

Berdasarkan hasil penelitian dapat disimpulkan bahwa:

1. Kesalahan pengetahuan deklaratif guru ini disebabkan oleh rendahnya tingkat pengetahuan deklaratif guru tersebut. Adapun pengetahuan deklaratif guru yang rendah yaitu pengetahuan guru tentang fakta dan konsep persegi, pengetahuan guru tentang dua daerah yang kongruen, dan pengetahuan guru tentang prinsip pythagoras.

2. Kesalahan pengetahuan deklaratif guru dalam membelajarkan matematika materi bangun datar adalah termasuk dalam kesalahan menyajikan informasi yang saling bertentangan.

\section{DAFTAR PUSTAKA}

Anderson, L.W dan Krathwohl, D.R. (2001). The Taxonomy of Educational Objectives, The Classification of Educational Goals, Handbook I: Cognitive Domain.
Australian Curriculum Assesment and Reporting Authority (ACARA). (2012). The Australian Curriculum: Mathematics. Sydney, Australia: ACARA.

Clark dan Mayer. (2007). Declarative Learning with Artifacts, Knowledge Creation Spiral.

Krathwohl, D.R.A. (2012). Revision of Bloom's Taxonomy: An Overview. Theory into Practice.

Madalina Tanase. (2011). Teaching Place Value Concepts to First Grade Romanian Students: Teacher Knowledge and its Influence on Student Learning; University of Nevada, Las Vegas.

Marzano, Robert J. (2009). What will I do to help students practice and deepen their understanding of New knowledge? Art and Science of Teaching, Chapter 3.

Miller dan Hudson. (2017). Using Evidence-Based Practices to Build Mathematics Competence Related to Conceptual, Procedural, and Declarative Knowledge: Learning Disabilities Research \& Practice, 22(1), pp. 47-57. The Division for Learning Disabilities of the Council for Exceptional Children.

Slava, Kalyuga. (2009). Knowledge Elaboration: A cognitive load perspective; Learning and Instruction; School of Education, University of New South Wales, Sydney, NSW 2052, Australia.

Subanji. (2007). Proses Berpikir Pseudo Penalaran Kovariasional Dalam Mengkontruksi Grafik Fungsi Kejdian Dinamik Berkebalikan. Disertasi tidak diterbitkan. Program Pascasarjana Unversitas Negeri Surabaya. 
| Jurnal PRIMATIKA, Volume 8, Nomor 1, Juni 2019

20 Profil kesalahan pengetahuan deklaratif guru SD

Zainuddin Untu 